\title{
Neighborhood Food Infrastructure and Food Security in Metropolitan Detroit
}

\author{
Scott W. Allard \\ University of Washington \\ Maria V. Wathen \\ Loyola University Chicago, mwathen@luc.edu \\ H. Luke Shaefer \\ The University Of Michigan \\ Sandra K. Danziger \\ The University Of Michigan \\ Follow this and additional works at: https://ecommons.luc.edu/socialwork_facpubs \\ Part of the Food Security Commons, Food Studies Commons, and the Social Work Commons

\section{Author Manuscript} \\ This is a pre-publication author manuscript of the final, published article.
}

\section{Recommended Citation}

Allard, Scott W.; Wathen, Maria V.; Shaefer, H. Luke; and Danziger, Sandra K.. Neighborhood Food Infrastructure and Food Security in Metropolitan Detroit. The Journal of Consumer Affairs, 51, 3: 566-597, 2017. Retrieved from Loyola eCommons, Social Work: School of Social Work Faculty Publications and Other Works, http://dx.doi.org/10.1111/joca.12153

This Article is brought to you for free and open access by the Faculty Publications and Other Works by Department at Loyola eCommons. It has been accepted for inclusion in Social Work: School of Social Work Faculty Publications and Other Works by an authorized administrator of Loyola eCommons. For more information, please contact ecommons@luc.edu.

\section{(c) $($ () $\ominus$}

This work is licensed under a Creative Commons Attribution-Noncommercial-No Derivative Works 3.0 License.

(C) The American Council on Consumer Interests 2017 
Neighborhood Food Infrastructure and Food Security in Metropolitan Detroit

\author{
Scott W. Allard \\ Professor \\ Evans School of Public Policy and Governance \\ University of Washington \\ Box 353055 \\ Seattle, WA 98195-3055 \\ sallard@uw.edu \\ 206-221-4872 \\ Maria V. Wathen \\ Assistant Professor \\ School of Social Work \\ Loyola University Chicago \\ 820 N. Michigan Ave \\ Chicago, IL 60611 \\ mwathen@luc.edu \\ 312-915-7005 \\ H. Luke Shaefer \\ Associate Professor \\ School of Social Work \\ University of Michigan \\ 1080 S. University Ave \\ Ann Arbor, MI 48109-1106 \\ 1shaefer@umich.edu \\ 734-764-3309 \\ Sandra K. Danziger \\ Professor \\ School of Social Work \\ University of Michigan \\ 1080 S. University Ave \\ Ann Arbor, MI 48109-1106 \\ sandrakd@umich.edu \\ 734-764-3309 \\ June 2017 \\ Forthcoming at the Journal of Consumer Affairs
}




\begin{abstract}
Concern about spatial access to food retailers and its relationship to household food security has increased in recent years, placing greater importance on understanding how proximity to food retailers is related to household food consumption. Using data from the Michigan Recession and Recovery Study (MRRS), a panel survey of working-age adults in the Detroit Metropolitan Area, this paper explores whether access to the food retailers is associated with food insecurity. We use unique data about food retailers in metropolitan Detroit to develop an array of food retailer access measures that account for distance to nearest retailer, density of retailers, commute times, mode of transit, and type of retailer. Across most measures, we find that many vulnerable population groups have greater or at least comparable spatial access to food resources as less vulnerable populations groups. There is little evidence, however, that greater access to food retailers is associated with food security.
\end{abstract}




\section{INTRODUCTION}

Driven in part by the lasting economic effects of the Great Recession, rates of food insecurity in the U.S. - the share of persons unable to reliably access an adequate amount of food - remain quite high even during the economic recovery of the last several years. In $2015,12.7 \%$ of all households were food insecure at some time during the year, down from 14.0 in 2014 and well-below a peak of 14.9 in 2011. From 1998 to 2007, however, roughly $11 \%$ of all households were food insecure (Coleman-Jensen et al. 2016). Consistent with these trends in food insecurity, Supplemental Nutrition Assistance Program (SNAP) participation rates increased by over $80 \%$ from 2007 to 2013. Today, caseloads have started to decline slightly, yet still an average of 45.8 million persons receive SNAP each month. ${ }^{1}$ Findings that SNAP participants are less likely to be food insecure than eligible non-participants (Kreider et al. 2012) underscore the seriousness of the increase in food insecurity during this time period. Nonprofit food pantry use also increased during the Great Recession (Oliveira 2016).

At the same time, a large literature has emerged to examine the presence of "food deserts," where limited spatial access to large supermarkets is thought to be associated with lower household food security for adults and children. Many definitions or thresholds of what constitutes a food desert or low food retailer access can be found in the research literature, leading to a mix of findings about the prevalence of low food retailer access in the U.S. today. Low food access is defined by the USDA as being in a census tract that is more than 1 mile from a supermarket or large grocery store in urban areas or more than 10 miles away in rural areas. By

1. There is evidence that policy changes in the early 2000s expanding access and eligibility, overturning many restrictive policies that welfare reform imposed on SNAP in 1996, contributed to increases in SNAP participation before the Great Recession. After the Great Recession, however, evidence suggests the vast share of the increase in SNAP participation has been driven by the program's response to rising need and joblessness (Andrews and Smallwood 2012; Ganong and Liebman 2013). 
this definition, 13.6 million persons in 6,529 census tracts live in food deserts (USDA 2016). ${ }^{2}$ There is particular concern among researchers and policymakers that poor neighborhoods and those neighborhoods with high percentages of racial and ethnic minorities have less access to food retailers than higher income neighborhoods or areas where whites compose a large share of the population (Bitler and Haider 2011). Limited access to food in low-income or racially segregated neighborhoods is thought to compound other economic and structural disadvantages experienced by residents. In response to these concerns, the Obama Administration created the Healthy Food Financing Initiative in 2010 to bring grocery stores into underserved areas and improve access to food retailers. Combined, these trends in research and policy place greater importance on understanding the connections between food resource access and food insecurity (Nord and Golla 2009; Pan and Jensen 2008; Shaefer and Gutierrez 2013; Yen et al. 2008; Kreider et al. 2012). Yet, there are relatively few studies that can link precise measures of food retailer access to household food security.

Using data from the Michigan Recession and Recovery Study (MRRS), a survey of a representative sample of working-age adults in the Detroit Metropolitan Area, this paper examines how access to local food resource infrastructure varies across households and geography. Detailed information about the location of households and SNAP-authorized food retailers in metro Detroit allows us to measure household spatial access to a host of food retailer types, from large-chain supermarkets to non-chain grocery stores to non-grocery outlets. We take advantage of information about household location and characteristics to examine food retailer access across key population sub-groups and local geography. We then model household food security as a function of food retailer access, household employment and income, and relevant

2. The median U.S. household is .83 miles to the nearest supermarket, see Ver Ploeg et al. 2012. 
household demographic characteristics including race, age, marital status, number of children in household, education level, work-limiting health condition, access to a car, and financial hardship. Financial hardship indicates whether a household was behind on utility payments, behind on rent or mortgage, had a credit card cancelled, took out a payday loan, or filed for bankruptcy in the previous 12 months.

Consistent with past research, we find food insecurity to be more prevalent among black households, households with low levels of income, respondents experiencing unemployment, and urban residents. We also find that low-income households, blacks, and urban residents have as good or greater spatial access to many different types of SNAP food retailers than higher income, non-black, or suburban households. We find no statistically significant differences in the average distance to the nearest SNAP large-chain supermarket or grocery store across race or income subgroups. Lower income households, blacks, and urban residents, however, are closer to small chain and non-chain grocery stores, as well as non-grocery food outlets such as convenience stores, in metro Detroit than higher income households, non-blacks, and suburban residents. Households with access to a car are within a 10-minute commute of a larger number of food retailers of all types than households who may be reliant on transit or walking to shop for food. When we model food security status as a function of household characteristics and spatial access to food retailers, however, we find no consistent significant relationships between greater access to food retailers and household food security. Rather, in alignment with past research on food security, we find that respondents with a high school degree or less, respondents with a work-limiting health condition, households experiencing periods of unemployment and financial hardship, and households with low levels of income are more likely to experience food insecurity (Coleman-Jensen et al. 2016; Gundersen, Kreider, and Pepper 2011; Nord et al. 2010). 
We believe that our findings will be of interest to a wide variety of scholars and policymakers. First, although nested within the Detroit metropolitan area, we provide clear evidence that it is important to consider access to a wide range of food retailers when exploring the prevalence of food deserts. Studies that focus only on chain supermarkets likely provide biased impressions of food retailer access. Our findings also show the value of thinking about access in terms of simple distance, but also by commuting times and modes. Next, our results suggest that efforts to address food access should focus on vulnerable groups in cities and in suburban areas, the latter which often are overlooked in research on food security and food deserts. Finally, our findings suggest the need for improved understanding of the spatial antecedents of food insecurity, particularly if the goal is to develop effective and efficient strategies that will increase the capacity of low-income households to purchase food.

\section{UNDERSTANDING FOOD SECURITY AND ITS RELATIONSHIP TO FOOD RETAILER ACCESS}

A household's level of food security is commonly determined by whether adults and children in the household have adequate access to food. Food secure households are those with reliable and regular access to food adequate for living; food insecure households are those with low levels of food security, manifested as limited access to adequate food due to lack of money and other resources. Severe levels of food insecurity involve more frequent disruptions in eating patterns and periods of reduced food intake (Coleman-Jensen et al. 2012). Most often researchers create measures of food security based upon a 6-item or 18-item Food Security Survey contained in the Current Population Survey (CPS), which asks households about the incidence and frequency of inadequate food consumption in the past year. Drawing on these survey data, it is estimated that about 1 in 8 Americans are food insecure today (Coleman-Jensen, et al. 2016). 
Researchers identify a number of common factors related to the higher likelihood of being food insecure. Research consistently finds low-income households more likely to be food insecure than non-poor households (Coleman-Jensen et al. 2016; Gundersen, Kreider, and Pepper 2011). Individuals with lower levels of completed education are more likely to experience food insecurity (Nord et al. 2010). Unemployment and earnings volatility are associated with heightened risk of food insecurity (Campbell and Desjardins 1989; Gundersen, Kreider, and Pepper 2011; Sullivan, Turner, and Danziger, 2008). Poverty is more prevalent among singleparent households with children and racial or ethnic minorities. It is not surprising, therefore, that scholars have found single-parent households, blacks, and Hispanics to experience food insecurity at rates substantially above the national average (Coleman-Jensen et al. 2016).

Even though the food security literature emphasizes individual- or household-level causal factors, food shopping, preparation, and consumption are embedded in the local communities and neighborhoods where people reside, work, and attend school. And in fact, there is evidence that food insecure households are more likely to live in higher poverty counties, zip codes, and tracts (Bartfeld, Ryu, and Wang 2010). Data from the late 1990s and early 2000s suggest that nonmetropolitan areas had slightly higher rates of food insecurity (Nord 2002), yet more recent studies find food insecurity to be more prevalent in central cities or areas with greater urbanicity than suburbs and rural areas (Bartfeld, Ryu, and Wang 2010; Coleman-Jensen, McFall, and Nord 2013). Finally, recent work has found food insecurity to be more prevalent in geographic areas of higher average grocery prices (Gregory and Coleman-Jensen 2013). The geographic areas used in this study are metro areas or larger.

There are many other features of the spatial context that may shape household experiences with food insecurity. We focus on the most commonly cited feature of the local food 
resource infrastructure: spatial proximity or access to food retailers within one metro area. Spatial access to food retailers may affect household food purchases and consumption for many reasons. All things being equal, living closer to a food retailer should translate into lower transaction costs associated with shopping. Proximity may be particularly important for lowincome households, for whom commuting costs may be particularly burdensome. Living in closer proximity to food retailers also is thought to make it easier for those with limited mobility, whether due to lack of access to a car or physical health conditions, to shop for food. Apart from transaction costs and convenience, many argue that being close to larger grocery stores or chain supermarkets corresponds to overall lower food purchase prices. Large-chain supermarkets may offer lower prices, either because they are more likely to carry generic brands, or because they carry products in bigger units that may allow savings per unit (Chung and Myers 1999;

Hendrickson et al. 2006; Morris et al. 1992). For a variety of reasons, therefore, greater spatial proximity to food retailers may be expected to be associated with increased household food consumption among vulnerable and resource-constrained households.

Racial and ethnic minorities, disproportionately likely to be poor and more likely to be segregated in high-poverty areas, may be at greater risk of living with low levels of food retailer access compared to whites. Predominantly black and Hispanic neighborhoods have been found to have less access to supermarkets and large-chain grocery stores than predominately white areas (Walker, Kean, and Burke 2010). For example, Gallagher (2006) finds that residents of majority black neighborhoods in Chicago have to travel almost $40 \%$ farther on average to reach the nearest chain grocery store compared to residents of majority white neighborhoods (.77 miles versus .57 miles on average). Nationally, zip codes with "higher proportions" of AfricanAmericans have half as many chain grocery stores than zip codes with higher proportions of 
whites (Powell et al. 2007). Lower income areas also have been found to contain fewer chain grocery stores than middle or upper income areas (Powell, et al. 2007; Moore and Diez Roux 2006). A study of three communities located in Maryland, New York, and North Carolina finds that "predominantly white" and affluent census tracts contain twice as many supermarkets on average than predominantly black and poorer areas after controlling for population size (Moore and Diez Roux 2006). Similarly, Zenk et al. (2005) find that high-poverty predominantly African-American census tracts in Detroit are about 1.1 miles farther from the nearest chain supermarket compared to high-poverty predominantly white tracts in Detroit.

Despite the intuitive logic behind concerns about spatial access and great effort to define places with low levels of access to food retailers, the empirical evidence is somewhat mixed on the degree to which inequality in food retailer access is present. In large part, variations in findings appear due to differences in study design, measurement, or operationalization. The nature of race and class differences in access to food retailers may shift depending on how food store access is conceived. For example, Raja, Ma, and Yadav (2007) compare the number of supermarkets, smaller grocery, and specialty food retailers located within five-minute commutes of white, black, and racially mixed census block groups in Erie County, NY. In contrast to other studies, the authors find that black and racially mixed neighborhoods are within a five-minute drive of roughly the same number supermarkets as white neighborhoods. The authors also find evidence that black and racially mixed neighborhoods tend to have far greater access to smaller grocery or specialty food retailers within a five-minute drive than white neighborhoods. Powell et al. (2007) and Moore and Diez Roux (2006) find race and class inequalities in access to supermarkets, but each study finds black and low-income areas to have greater access to nonchain groceries than white and higher income areas. Allocating 2000 Census block data to 1- 
square kilometer grids, a study by the US Department of Agriculture (2009) finds that the median non-white household nationally is 0.63 miles from the nearest supermarket compared to 0.96 for the median white household. Nationally, the same study concludes that $4.1 \%$ of lowincome persons living in low-income areas - about 11.5 million people - are more than 1 mile from a supermarket.

Results from a small number of studies provide some guidance about the possible impact of food access on household food outcomes. Self-reported access to public transportation reduces odds of food insecurity among households with elementary-age school children in Wisconsin significantly, but living a very long distance from the nearest grocery store - 15 to 22 miles increases the odds of being food insecure by $67 \%$ (Bartfeld, Ryu, and Wang 2010). Food stamp households living within a mile of the store where they primarily shop are found to consume greater than $30 \%$ more fruit per day than similar households living five miles or more from the grocery or food store where most of the shopping was done (Rose and Richards 2004). Selfreported perceptions of high grocery prices and too few local supermarkets or grocery stores are found to be related to food insecurity among rural residents in two study counties in Iowa.

Very few studies can link food retailer access to individual or household food behavior, however, which makes it difficult to assess at what levels, thresholds, or tipping points access matters. Studies often find statistically significant differences in access between different types of tracts, but it is not clear if these statistically significant differences are substantively meaningful to food insecure households. Food security measures most often are gathered from surveys of large nationally representative samples, meaning there are few data sources that collect detailed food security measures and can locate survey respondents with geographic precision. Commonly used datasets, such as the Current Population Survey (CPS) or Survey of 
Income and Program Participation (SIPP) public use files, only contain general measures of geography (i.e., region or state identifiers; inside or outside of metropolitan statistical areas) and these data generally are less accurate at lower levels of geographic aggregation (e.g., county or metropolitan area). Information about food security in these surveys comes at too high a level of aggregation to think precisely about most types of place effects. National surveys also do not contain long enough panels to track spatial variation over time (e.g. CPS) or do not have enough observations in a given place to permit spatial analyses of local place factors (e.g., SIPP).

\section{DATA AND METHODS}

This is one of the first studies, to our knowledge, that examines directly the relationship between access to local food retailers and food security using representative survey data when controlling for a rich set of household characteristics. We draw upon two unique data sets to construct spatial measures of food retailer access and analyze their relationship to food security. First, we pool survey data from Waves 1 and 2 of the Michigan Recession and Recovery Study (MRRS), a representative sample of working-age adults in the Detroit Metropolitan Area. The MRRS is a probability sample of adults between the ages of 18 and 64 residing in the Detroit Metropolitan Area (Macomb, Oakland, and Wayne counties) in Fall 2009. When survey weights are applied, the MRRS sums to the American Community Survey (ACS) estimated total population count for the three-county metro area and to totals for key sub-population groups (Adams et al., 2011). Wave 1 of the MRRS completed hour-long, in-person interviews between October 2009 and March 2010 with 914 respondents; the response rate was $82.8 \%$. Wave 2 was fielded between April and August 2011 and completed interviews with 93.0\% of Wave 1 respondents who survived until Wave 2. 
Each MRRS wave contains detailed information about employment history, earnings, assets, education and training, income sources, public program participation, material hardships, food security, debts, housing conditions, health and mental health, martial and relationship status, and basic household demographics. In this paper, we pool observations across the two waves of the MRRS to model the relationship between the local food infrastructure and food security, while also accounting for relevant household-level characteristics. ${ }^{3}$ To examine the relationship between food retailer access and food security among households most vulnerable to being food insecure, we restrict our sample to households with low income, which we define as those below $300 \%$ of poverty in a given survey year. ${ }^{4}$

Our measure of food insecurity is based on five items from a six-item battery in the December CPS module..$^{5}$ At each wave, respondents answered five questions about food purchases and consumption in the 12 months prior to the survey. The responses were used to assess household food insecurity. Specifically, respondents were asked if each statement was often, sometimes, or never true for them.

1) The food they bought just didn't last, and they didn't have money to get more.

2) They couldn't afford to buy balanced meals.

3) They or other adults in household cut the size of their meals or skipped meals because there wasn't enough money for food.

3. We pool data from two waves of the MRRS, adjusting standard errors to account for repeated person observations. This has the effect of stacking two representative samples, which increases sample size and ensures that findings hold over two time periods. Analysis of stacked samples across years such as this are common with cross-sectional as well as panel micro data (Greider, Pepper, Gundersen, and Jolliffe, 2012; Gruber \& Simon, 2008; Ratcliffe, McKernan and Finegold, 2008; Shaefer Grogan and Pollack, 2011). Future research will exploit the MRRS panel structure to examine outcomes longitudinally.

4. Household income takes into account the respondent's and other household adult's income from all cash sources in the prior tax year and is compared to Federal Poverty Level thresholds. We have conducted sensitivity analysis using both 200 and $250 \%$ of the poverty line. The results are similar, coefficient signs are unchanged, and standard errors are larger.

5. Wave 1 contained only five of six items from the USDA six-item food security scale collected each December in the Current Population Survey (CPS); Wave 2 contained all six items from the December CPS module. The omitted question in Wave 1 followed question 3. If households indicated that adults cut the size of their meals or skipped meals because there wasn't enough money for food, they should have been asked whether this happened almost every month, some months but not every month, or in only 1 or 2 months. 
4) They ate less than they felt they should because there wasn't enough money to buy food.

5) They were hungry but didn't eat because they couldn't afford enough food.

We summed the number of responses indicating "often" or "sometimes" to these five questions to create a 0 to 5 scale score reflecting household food insecurity. ${ }^{6}$ Households with scores of 0 or 1 are defined as food secure, while households with summed scores ranging from 2 to 5 are defined as food insecure. ${ }^{7}$

Table 1 reports the characteristics of our sub-sample taken from the MRRS. We find that 43.7\% of respondents self-identified as black and 33.1\% lived within the city of Detroit. Almost half of households had children in them (43.9\%), while $35.0 \%$ of our subsample reported annual household income at less than $100 \%$ of poverty. Roughly $84 \%$ of sample households were headed by individuals with less than a bachelors' degree, and more than half of all household heads had been out of work for at least a month over the course of the previous year. More than a third of households reported experiencing financial hardship over the past 12 months. We find a high rate of car ownership or leasing, at $69.2 \%$ of households.

[Table 1 about here]

The bottom row of column 1 in Table 1 reports the prevalence of food insecurity in our MRRS sample. More than one-third (37.8\%) of our sample indicate they are food insecure at the time of the survey. The second and third columns of Table 1 provide a sense of the demographic differences between those who are food insecure versus secure by the measure available in the

6. We find almost no difference in the prevalence of food insecurity when comparing the five-item measure against the full six-item measure in Wave 2. We also do not find significant differences in the characteristics of food insecure households between Wave 1 and 2 of the MRRS.

7. We also ran models using a three-category variable of food secure, low food security, and very low food security, though we recognize that this is not an official distinction. Households with scores of 0 or 1 were defined as having high or marginal food security, households with scores of 2 to 4 indicated low food security, and those with scores of 5 are defined as having very low food security. The findings from these models were nearly identical to those of the dichotomous food insecurity variable. 
MRRS. We find that only $31.4 \%$ of non-black respondents are in households that are food insecure versus $46.1 \%$ of black respondents. ${ }^{8}$ Nearly half of Detroit residents are food insecure, compared to a little more than one-quarter of suburban residents. Households with income below $100 \%$ of poverty are more likely to be food insecure than those between $100 \%$ and $300 \%$ of poverty (48.9\% versus $31.8 \%$ ). Similarly, we find respondents without a college degree to have much higher rates of food insecurity than those who completed a college degree. Consistent with expectations about shocks to household employment and earnings, we find those with any spell of unemployment or time out of the labor force in the prior 12 months have much higher rates of food insecurity than those who remain in the labor force and employed for the 12 months prior to the survey. In contrast to expectations and past research findings, respondents 19 to 24 years of age were less likely to be food insecure than older respondents.

The second source of data for this article comes from publicly available lists of authorized SNAP retailers from the USDA's Food and Nutrition Service program. Specifically, we utilize information about food retailers in the Detroit Metropolitan Area for the years 2008 and 2010 authorized to receive SNAP. These data provide a comprehensive and updated list of food retailers, which is critical to generate accurate measures of food retailer access. The 2008 data indicate the presence of 3,488 total retailers authorized to receive SNAP; there were 4,292 total retailers authorized to receive SNAP in 2010. It is difficult to estimate what share of food retailers in Detroit accept SNAP, but we should expect that most, if not all, large-chain supermarkets or grocery stores in Detroit metropolitan area accept SNAP benefits, as well as the vast majority of larger non-chain groceries. Many convenience stores or non-grocery retailers

\footnotetext{
8. The racial and ethnic background of non-black respondents in the MRRS include non-Hispanic white (89.9\%); Native American/Alaskan Native (3.0\%), Hispanic (2.2\%), Asian Indian (1.7\%), Arab (1.2\%), Chinese (0.7\%), Japanese (0.5\%), Other Asian/Pacific Islander (0.5\%).
} 
(e.g., bakeries) also accept SNAP benefits.

Yet, apart from store name and street address location, there is no other information about the food retailers in these data. ${ }^{9}$ When sorting by store name, it was possible to identify large regional or national chain supermarkets or grocery stores (e.g., Kroger) or a chain drug store, dollar store, non-food retailer (e.g., CVS, a chain drug store). For example, for the 2008 list of retailers we were able to identify 302 large-chain supermarket or grocery stores and 686 chain drug or dollar stores. Many stores in each year, however, could not be coded by store name alone. To add information about store type to these retailers, therefore, a team of research assistants viewed each retailer through Google Maps by entering the address and locating the building in street view. Using the street view image of the store and the store name, the team sorted all stores into one of seven categories: Grocery store/Chain Grocery (e.g.., Kroger); Drug Store/Dollar Store/Chain Retail (e.g., CVS, Target, Dollar Store); Gas Stations; Mini-mart, Convenience, Liquor or Party Stores; Specialty Foods (e.g., bakeries, butchers); Farmers Market; and an "other" category where there was no information visible about the nature of the retailer to assign a code. ${ }^{10}$ Only food retailers that provided visual evidence via Google Maps Street View of carrying a full line of groceries, including fresh produce, were coded as a supermarket or grocery store. For example, to identify retailers as grocery stores, coders looked for large parking lots, carts or cart stands, store signs advertising fresh vegetables, fruits, or meats, or outside displays of fruit and vegetables. Similarly, the presence of gas pumps, small store space, and signage for carry-out food or alcohol in the absence of fresh foods signage was often used to classify retailers as non-grocery outlets.

9. Ideally, we would have information about sales volume or market share, but those data are not available in these lists of food retailers.

10. There were 52 retailers coded as "other" in 2008 and 89 in 2010. 
For the purposes of analyses presented here, we consolidated these seven categories into three broad categories. First, we coded supermarkets or grocery stores as large-chain retailers if there were 5 or more separate entries with the same name in the FNS SNAP retailer database. There were 302 large-chain retailers in metro Detroit in 2008 and 344 in 2010. Grocery stores with 4 or fewer were considered non-chain grocery stores. Our coding identified 249 non-chain retailers in metro Detroit in 2008 and 251 in 2010. Finally, we placed drug or dollar stores, gas stations, mini-mart or convenience stores, specialty food stores, and all other stores into a nongrocery retailer category. In 2008, there were 2,937 non-grocery retailers in metro Detroit and 3,698 in $2010 .{ }^{11}$ Given the limited parameters of this coding scheme, we believe that our estimates provide a conservative estimate of available grocery stores. That is, stores coded at specialty shops or convenience stores might, in actuality, carry a line of groceries that is broad enough for a family to meet all their food needs. Coding of stores was cross-checked for consistency.

\section{Calculating Food Retailer Access}

SNAP food retailer data from 2008 was used to create measures of retailer access for Wave 1 respondents; SNAP food retailer data from 2010 was used to create measures of access for Wave 2 respondents. Store addresses for SNAP food retailers were geocoded and geographic coordinates of each store were then added to the GIS. Store coordinates were used to match food

11. There are two likely explanations for the increased observation of non-grocery stores in metro Detroit from 2008 to 2010, although our data do not allow us to explore why there was such an increase. First, these figures suggest that many new drug stores, dollar stores, or convenience stores could have opened between 2008 and 2010. Given that this was a recessionary period, however, it may be that a larger number of non-grocery retailers received authorization to accept SNAP benefits due to rising caseloads and efforts to draw sales from SNAP participants. When comparing measures of spatial access to food retailers of all types between Wave 1 and 2 , however, we find no significant differences over time. This suggests that most MRRS respondents did not experience a meaningful change in food retailer access between waves of the survey. 
resources to MRRS respondents in terms of distance in miles, and by various methods of commute-walking, driving, and public transit. Food retailer access measures were calculated in each wave by determining time and distance between each MRRS respondents' home and a given type of food retailer. Addresses of the respondents from two waves are geocoded to 2010 Census geography. We report several different measures of food retailer access below. First, we report straight-line or Euclidean distances between respondent household locations and each food retailer, which were calculated by taking the distance between the coordinate points of each. We identify distance to the nearest food retailer, as well as counts of food retailers within 1-, 2-, and 3-mile distance bands. Taking into account commute times and modes, we also calculate access measures that sum of the number of food retailers of a given type located within a 10minute commute time of each MRRS respondent's home for three different travel modes: driving; public transit; and walking. ${ }^{12}$

We believe this approach to defining access to food retailers provides valid and accurate measures of spatial proximity to food retailers. First, we examine access across a large array of store types. Second, we are able to determine distance and travel times across multiple modes using the exact location of both households and food retailers. Third, we can compare urban to suburban residents of a large metropolitan area. Finally, we are able to compare access across

12. A least cost driving time measure was calculated in ArcGIS using the routing service data from the StreetMap North America dataset 10.1 to determine the route that minimized travel distance or represented the shortest route. When determining the minimum travel distance, we restricted the use of private entryways, waterways and toll roads and asked for routes to that minimized travel time (i.e. time as the impedance, or the quickest route). Walking time was also calculated in ArcGIS and using the same routing service data, with the added restriction that access roads, namely highways, could not be used as walkways for pedestrians. Once the shortest travel route was assigned for each trip between the participant's residence and a destination, the distance was then translated into travel time assuming an average comfortable walking speed of 3 miles per hour. Calculation of the public transit travel time was done in Stata, where a "TRAVELTIME" command file retrieved estimated public transit travel time using the Google Transit web service and assuming the Detroit public transportation system (SMART) as the mode of transportation. It should be noted that public transit travel time varies by time and day of the travel. The time of the travel we used was 9am, and the day of the travel was Wednesday, September 26, 2012. 
household characteristics - not geographic units or polygons. Combined, we believe our data in metropolitan Detroit allow us to measure food retailer access with greater accuracy than most prior research. Moreover, unlike many studies, we are able to link these more granular measures of food retailer access to household food security.

\section{DESCRIPTIVE FINDINGS}

Table 2 presents some findings on the Euclidean or straight-line distance between MRRS sample members and SNAP food retailers. First presented in the left hand panel is the average distance in miles to the nearest SNAP retailer by household characteristics. We present access to four types of SNAP retailers: 1) all chain and non-chain grocery stores combined; 2) large-chain supermarkets; 3) non-chain grocery stores, and 4) non-grocery SNAP retailers. The second set of estimates in the right hand panel of Table 2 shows the percent of households within 1 mile of at least 1 SNAP retailer in each of the categories - a measure consistent with USDA guidelines for low access areas.

Across both panels we find little evidence that households commonly identified as vulnerable to having low food access are farther on average from SNAP food retailers than households often thought to be less vulnerable. For example, although non-black households live closer to large-chain grocery stores than black households, black households live almost threefourths of a mile closer to a non-chain grocery store on average than non-blacks (0.91 miles versus 1.59 miles respectively). More than half of black and non-black households live within 1 mile of a large-chain grocery store $(51.0 \%$ and $67.7 \%)$, but $74.6 \%$ of blacks live within 1 mile of a non-chain grocery store, compared to only $36.0 \%$ of non-blacks. When we combine chain and non-chain groceries into a single access measure, we find that black respondents are .55 miles 
from the nearest retailer and non-black respondents are .71 miles from the nearest retailer - but the mean difference between the two sub-groups is not statistically significant (first column of Table 2). Both black and non-black respondents are within a half mile of a non-grocery store accepting SNAP.

[Table 2 about here]

We find households with income below $100 \%$ of the federal poverty measure to be about one mile from the nearest large-chain grocery store, as are households with income between 100 and $300 \%$ of poverty. Poor households, however, are closer to SNAP non-chain groceries and non-grocery stores than households with income between 100 and $300 \%$ of poverty. Households with income below federal poverty are located an average of 1.01 miles from a non-chain grocery, compared to 1.45 miles for those with income between 100 to $300 \%$ of poverty. Nearly $70 \%$ of lower income households live within 1 mile of a non-chain grocery, compared to $45 \%$ of higher income households. In short, poor households live closer to SNAP non-chain grocery and SNAP non-grocery stores than do higher income households, but there is no significant difference in their distances to large-chain grocery stores.

We do find that Detroit residents on average are about half of a mile farther from the nearest large-chain supermarkets than suburban residents. Yet, Detroit residents are more than a mile closer, on average, to a non-chain grocery store. Nine of ten Detroit residents live within a mile of a non-chain grocery store, while this is true of only a third of suburban residents. When looking at access to all chain and non-chain groceries together, we find Detroit residents to be within a half mile of a retailer on average, compared to .71 of a mile for suburban residents. These findings are consistent with work by Taylor and Ard (2015), which found that many of the 
Detroit census tracts labeled as food deserts by the USDA did not meet that threshold when independent grocery stores were taken into account.

Most relevant to the questions at hand, we do not find households experiencing food insecurity are farther, on average, from large-chain supermarkets than households that are food secure. In addition, there is evidence that a larger proportion of food insecure households are within 1 mile of a SNAP non-chain grocery than food secure households (57.0\% compared to $50.3 \%)$

We also examine access to food retailers among households with limited mobility. For example, respondents with a work-limiting health condition live on average 1.11 miles from a non-chain grocery store, whereas those with no such condition live 1.36 miles from a non-chain grocery on average. In addition, a higher percentage of household heads with a work-limiting health condition live within 1 mile of a SNAP non-chain grocery than those without such a condition, at $64.6 \%$ to $48.7 \%$. For household respondents with a work-limiting health condition, there was no significant difference in distance to large-chain grocery stores compared to their comparison group. Nevertheless, for those with limited mobility, traveling more than a few blocks or a half-mile to a grocery store may be obstacle enough and the findings about mean differences in access may not be as relevant. A similar pattern holds for households without a car. Households that do not own or lease a car live in areas slightly closer to non-chain grocery and non-grocery stores on average than households with a car. Nearly seven in ten households without a car, however, live within 1 mile of a SNAP non-chain grocery store; slightly less than half of households with a car are within 1 mile of a SNAP non-chain grocery store. Households with a car do live closer on average to large-chain grocery stores than those without a car, but 
when combining average distances to large-chain and non-chain grocery stores, there are no significant differences between these two groups.

Neighborhoods located near greater densities of food retailers may have more choice, better quality food items, and more affordable prices than neighborhoods with less store density, all things being equal. Thus, we report the number of SNAP retailers within radii of 1 mile, 2 miles, and 3 miles of MRRS households in Table 3. Findings in Table 3 are quite consistent with those in Table 2. For example, we see black households live in areas with fewer large-chain grocery stores on average than non-blacks. The average black household in the MRRS is within 2 miles of 2.4 large-chain grocery stores, but the average non-black household is within 2 miles of 4.1 large-chain stores. Blacks, however, are within 2 or 3 miles of three times as many nonchain grocery stores as non-blacks. Similar patterns are observed across Table 3 when comparing income groups, urban versus suburban status, and households by food security level.

[Table 3 about here]

Straight-line distance measures of food retailer access, however, may mask the accessibility of food retailers for those with limited access to cars or without nearby public transportation services. Taking advantage of our unique household data in metro Detroit, therefore, we report access measures in Table 4 that indicate the number of stores within a 10minute commuting time by driving, walking, or public transit. Several findings stand out in Table 4. First, it is clear that households able to use a car to shop for groceries brings a larger number of food retailers within a 10-minute commute than households who may be reliant on transit or walking to shop for food. For example, there are a large number of large-chain food retailers - 15 to 17 on average - within a 10-minute drive of most residents of metro Detroit. By comparison, a 10-minute walking or public transit trip brings the average resident of 
metropolitan Detroit in contact with less than 0.5 large-chain food retailers. Apart from differences in the number of large-chain retailers accessible through 10-minute drives versus other commuting modes, there are no subgroup differences in access to large-chain retailers across driving, walking, or transit.

[Table 4 about here]

Substantively and statistically significant differences in access to non-chain grocery and non-grocery food retailers are evident when contrasting 10-minutes commutes by car, foot, or public transit. Detroit residents are within a 10-minute drive of 42.8 non-chain grocery stores, compared to 9.1 non-chain stores for suburban residents. Our data suggest that city residents with cars have access to more than twice as many large-chain and non-chain grocery stores within a 10-minute drive as suburban residents with a car. Detroit residents are within a 10-minute public transit commute of 1.1 non-chain grocery retailers on average, yet the average suburban resident cannot access a single non-chain grocery store in 10 minutes by bus (0.1 SNAP retailers). The average MRRS respondent cannot access a non-chain grocery within a 10-minute walk, but Detroit residents are within a 10-minute walk of nearly four times as many non-grocery food retailers on average as suburban residents.

We see significant differences in access to non-chain or non-grocery retailers across other key population sub-groups when looking at different commuting modes. These differences, however, largely are consistent with differences in access based on straight-line distance. For example, black households live within a 10-minute drive of 33.4 non-chain food retailers on average; non-black households live within a 10-minute drive of 10.0 non-chain food retailers on average. A similar pattern emerges across income groups. There are no statistically significant differences in the number of large-chain supermarkets for those below or above the federal 
poverty line. Households with income below federal poverty, however, have greater access to non-chain and non-grocery retailers across all commute modes compared to households with income between 100 to $300 \%$ of federal poverty.

Thinking through the manner in which research defines spatial access to food retailers is an important exercise. Different measures or approaches to defining access make particular assumptions above how access may or should matter, which are important to recognize. Our descriptive findings yield important differences in access across population subgroups and geography, but they also highlight how different measures or approaches yield similar results across population sub-groups and geography. While we find important differences in access between those with cars and those reliant on alternative modes of transportation to shop for groceries, we find no consistent evidence to indicate that blacks, low-income households, or those experiencing food insecurity have less access to chain or non-chain grocery stores than non-blacks, higher income households, and households with greater food security.

\section{ASSESSING THE RELATIONSHIP BETWEEN FOOD RETAILER ACCESS TO FOOD INSECURITY}

Another unique feature of our study is its ability to link food retailer access to the incidence of household food insecurity. Tables 5 reports a series of logistic regression models predicting food insecurity among households with income at or below $300 \%$ of poverty and food access measures. We report four different food access measures included separately in four models presented in Table 5: 1) average distance in miles to the nearest chain and non-chain grocery store; 2) average distance in miles to the nearest large-chain grocery stores; 3) average distance in miles to the nearest non-chain grocery store; and, 4) average distance in miles to the 
nearest non-grocery store. In addition to controlling for spatial access to food retailers, we include measures to reflect the racial composition of the household, age of the respondent, marital status, completed education, car ownership, income at or below $100 \%$ of poverty, unemployment, the presence of a work limiting health condition, and the experience of financial hardship in the previous month. Table 6 shows the odds ratios and standard errors for many additional food retailer access measures drawn from logit regressions of our dichotomous food insecurity variable. Reported odds ratios and standard errors for access measures are estimated in models that include a given access measure and the same set of control variables found in Table 5.

Several key findings stand out. Most striking, perhaps, is that across different specifications of food insecurity and across 23 different measures of food infrastructure access, we find no consistent evidence that access to food retailers is associated with food insecurity. Not only do we find coefficient estimates to fall far short of conventional levels of statistical significance, but coefficients are not of a consistent sign or direction. In many instances, coefficient signs are opposite what might be expected - the further the household is away from food resources, the less the risk of reporting food insecurity. Overall, with the exception of 2 of the 23 access measures, none of the coefficient estimates are statistically significant.

[Tables 5 and 6 about here]

Consistent with our expectations about the impact of economic shocks and income volatility on household food security, we find that households experiencing unemployment or spells out of the labor force in the previous 12 months are more likely to report food insecurity than households employed in each of the previous 12 months. We also find a positive relationship between the presence of a work-limiting health condition and food insecurity. 
Similarly, we find financial hardship in the prior twelve months positively related to household food insecurity. Households with income at or below $100 \%$ of poverty also are more likely to report food insecurity in the previous twelve months.

Other findings are consistent with past research findings. For example, respondents with lower levels of educational attainment are more likely to be in households that experience food insecurity. In contrast to our expectations, there is some evidence that respondents ages 25 to 34 are less likely to be food insecure than respondents ages $45-64$ years. When controlling for household income and labor market participation, we find married respondents are no less likely to be food secure than respondents who are not married or divorced. Households with children also are no more likely to be food insecure than households with no children. ${ }^{13}$ Owning or leasing a car is also not associated with household food security in this sample of Detroit residents.

We find black respondents to be no more or less likely to experience household food insecurity or more severe food insecurity than non-black households. We find nearly identical results when we limit our sample to blacks and non-Hispanic whites only. Such findings also may reflect the fact that respondents were interviewed in 2008 and 2010, at the start and end of the Great Recession. The recession and deteriorating economic conditions in the region prior to the official start of the downturn had a significant economic impact on blacks and non-blacks in metropolitan Detroit, possibly leading us to observe no significant relationship between race and food insecurity in this particular sample.

13. We estimated alternative models that included a dichotomous measure of whether there were children age 5 or under in the household and another set including a dichotomous measure of whether there were children age 12 or under in the household. The coefficients for these variables were positive and statistically significant, and the remaining results in the models did not change. In addition, we estimated a set of models that included measures for the number of children under 5 years old and the number of children 6 to 17 years old. Results again indicated a positive and significant relationship between the presence of the number of children in each age cohort and food insecurity. For simplicity, we proceed with the models as originally specified. 


\section{DISCUSSION}

In this study, we use unique data about households and precise measures of food retailer access in metropolitan Detroit to examine the relationship between food access and food insecurity. Our initial findings do not provide much support for most conventional hypotheses about access to food retailers. Across most measures, we find that many population groups thought most vulnerable to living in a food desert actually have greater or at least comparable spatial access to food resources than less vulnerable populations groups. There is one important exception - we find that access to a car provides households with access to many times more food retailers within a reasonable commute than would be the case if households were reliant on walking or public transit to shop for food. When modeling food insecurity as a function of spatial access to food retailers and a number of key household demographic characteristics, we find no evidence that proximity to SNAP-authorized supermarkets or grocery stores is associated with food insecurity.

We believe there are several key takeaways for researchers. First, our descriptive findings underscore the importance of examining all food retailers and not just large-chain retailers or convenience stores. When we account for non-chain grocery stores, we find there to be many more options for residents across metro Detroit than data about large-chain stores alone would indicate. Our work here also shows the importance of more precise food retailer access measures, which account for exact household geographic locations and travel times by different commute mode. Second, although we think of food deserts as an urban or rural problem, our findings suggest that suburban residents of Detroit have less access to food retailers than their urban neighbors. Such findings are consistent with recent discussion about the suburbanization of poverty and the challenges low-income families face in access to jobs, shopping, and social 
services in suburban areas (see , Berube and Kneebone 2013). Finally, even with better access measures, our findings suggest that proximity to food retailers may not be the critical ingredient to ensuring that people have adequate food.

Despite the precision of our food retailer access measures, there are several limitations of this study. First, we are focused on the Detroit metropolitan area, which has experienced particularly severe loss of population and employment opportunities in the last several decades. The spatial relationship between food resource access and household food security observed here might not be relevant to other settings. In particular, Detroit has a much longer experience of challenging economic conditions than most metro areas (Farley, Danziger and Holzer 2002), and a persistently weak local economy has contributed to much higher levels of SNAP utilization than found nationally (__ $)$. In addition, given our data's geographic scope, we cannot compare our findings of urban and suburban food insecurity in the Detroit metro area with nearby rural food insecurity. Another key limitation relates to the limited information we have about food pricing and selection from the lists of SNAP authorized retailers. We do not have information about what different stores sell, their prices, or quality. We know from our coding of stores that non-chain groceries are not confused for convenience stores, but we don't have any product or purchase information. Such limitations matter, as it may likely be that access to affordable food options across several types of retailers shapes household food security.

Nevertheless, we believe this paper provides some guides for research examining access to local food retailers and household food behaviors. While food retailer access may not be related to food security, access may be related to other important household food shopping or consumption outcomes. For example, households living in areas with greater grocery store density may be able to more easily shop for sales or bargains than households living in areas 
with less store density. New data from the USDA's FoodAPS (Clay et al. 2016) initiative should allow researchers to examine the relationship between household food purchases and food retailer access. Given the increases in SNAP caseloads over the past decade, it might be that greater access to food retailers accepting SNAP increases the likelihood that eligible households participate in SNAP. Participation in SNAP should increase household food purchasing power.

We also believe our findings have important implications for policy and practice moving forward. Perhaps most importantly, we believe the results reported here should lead scholars, advocates, and policymakers to reevaluate the logic models embedded in policy prescriptions that reduce food insecurity through making food resources more spatially accessible to vulnerable households. Again, it may be that access does matter - but the relationship may not be as straightforward as simply increasing spatial access to grocery stores or supermarkets. Our findings highlight the importance of employment shocks, low levels of income, and experience with financial hardship in understanding the prevalence of food insecurity today. Finding ways to connect economically vulnerable households with additional resources that increase household food budgets might prove to be most effective at reducing food insecurity in American society today. 


\section{TABLE 1}

MRRS Sample Characteristics for Households with Income at or Below 300\% of Poverty

\begin{tabular}{|c|c|c|c|}
\hline \multirow[b]{2}{*}{ Respondent Characteristic } & \multicolumn{3}{|c|}{ Percentage of ... } \\
\hline & $\begin{array}{c}\text { All } \\
\text { Households }\end{array}$ & $\begin{array}{l}\text { Food Insecure } \\
\text { Households }\end{array}$ & $\begin{array}{l}\text { Food Secure } \\
\text { Households }\end{array}$ \\
\hline \multicolumn{4}{|l|}{ Respondent Race } \\
\hline Black & 43.7 & $46.1^{\mathrm{a}}$ & $53.9^{\mathrm{d}}$ \\
\hline Non-black & 56.3 & $31.4^{\mathrm{a}}$ & $68.6^{\mathrm{d}}$ \\
\hline \multicolumn{4}{|l|}{ Household with children } \\
\hline Children & 43.9 & 36.9 & 63.1 \\
\hline No children & 56.1 & 38.4 & 61.6 \\
\hline \multicolumn{4}{|l|}{ Household Income } \\
\hline At or below $100 \%$ of poverty & 35.0 & $48.9^{\mathrm{a}}$ & $51.1^{\mathrm{d}}$ \\
\hline $100-300 \%$ of poverty & 65.0 & $31.8^{\mathrm{a}}$ & $68.2^{\mathrm{d}}$ \\
\hline \multicolumn{4}{|l|}{ Respondent Age } \\
\hline Age 19-24 & 15.4 & $24.4^{\mathrm{abc}}$ & $75.6^{\text {def }}$ \\
\hline Age $25-34$ & 21.6 & $44.2^{\mathrm{a}}$ & $55.8^{\mathrm{d}}$ \\
\hline Age $35-44$ & 18.9 & $40.2^{\mathrm{b}}$ & $59.8^{\mathrm{e}}$ \\
\hline Age $45+$ & 55.2 & $38.2^{\mathrm{c}}$ & $61.8^{\mathrm{f}}$ \\
\hline Respondent Married & 29.4 & 33.6 & 66.4 \\
\hline \multicolumn{4}{|l|}{ Respondent Education } \\
\hline Less than HS & 18.8 & $50.4^{\mathrm{ab}}$ & $49.6^{\mathrm{de}}$ \\
\hline HS but no BA & 65.8 & $39.7^{\mathrm{ac}}$ & $60.3^{\mathrm{df}}$ \\
\hline BA or more & 15.4 & $13.1^{\mathrm{bc}}$ & $86.9^{\text {ef }}$ \\
\hline \multicolumn{4}{|l|}{ Labor Force Participation in Last 12 Months } \\
\hline No months of unemployment or NILF & 40.7 & $28.0^{\mathrm{abc}}$ & $72.0^{\text {def }}$ \\
\hline 1-6 mos. Unemployed or NILF & 15.1 & $44.9^{\mathrm{a}}$ & $55.1^{\mathrm{d}}$ \\
\hline 7-9 mos. Unemployed or NILF & 5.8 & $48.9^{\mathrm{b}}$ & $51.1^{\mathrm{e}}$ \\
\hline 10-12 mos. Unemployed or NILF & 38.4 & $43.7^{\mathrm{c}}$ & $56.3^{\mathrm{f}}$ \\
\hline Work-limiting Health Condition & 27.4 & $54.2^{\mathrm{a}}$ & $45.8^{\mathrm{d}}$ \\
\hline $\begin{array}{l}\text { Household Financial Hardship previous } 12 \\
\text { months }\end{array}$ & 43.5 & $54.7^{\mathrm{a}}$ & $45.3^{\mathrm{d}}$ \\
\hline Owns or Leases a Car & 69.2 & 36.9 & 63.1 \\
\hline City of Detroit Resident & 33.1 & $47.7^{\mathrm{a}}$ & $52.3^{\mathrm{d}}$ \\
\hline Suburban Detroit Resident & 66.9 & $32.8^{\mathrm{a}}$ & $67.2^{\mathrm{d}}$ \\
\hline Food Secure & 62.2 & 0.0 & 100.0 \\
\hline Food Insecure & 37.8 & 100.0 & 0.0 \\
\hline$n$ & 960 & 417 & 543 \\
\hline $\begin{array}{l}\text { Notes: a,b,c - Cell-pair comparisons are statistice } \\
\text { applied. Results reflect households with income } \\
\text { waves. Source: Michigan Recession \& Recovery }\end{array}$ & $\begin{array}{l}\text { ent at the } .10 \text { le } \\
\text { w 300\% of the }\end{array}$ & $\begin{array}{l}\text { below. House } \\
\text { al Poverty Lev }\end{array}$ & $\begin{array}{l}\text { vey weights } \\
\text { pooled across }\end{array}$ \\
\hline
\end{tabular}




\begin{tabular}{|c|c|c|c|c|c|c|c|c|c|}
\hline \multirow[b]{2}{*}{ Respondent Characteristics } & \multicolumn{4}{|c|}{ Average Distance in Miles to Nearest SNAP Retailer } & \multicolumn{4}{|c|}{ Percent of Households within 1 mile of SNAP Retailer } & \multirow[t]{2}{*}{$n$} \\
\hline & $\begin{array}{c}\text { Large-Chain } \\
\& \text { Non-Chain } \\
\text { Grocery } \\
\text { Stores }\end{array}$ & $\begin{array}{l}\text { Large- } \\
\text { chain } \\
\text { Grocery }\end{array}$ & $\begin{array}{c}\text { Non-Chain } \\
\text { Grocery }\end{array}$ & $\begin{array}{c}\text { Non- } \\
\text { Grocery }\end{array}$ & $\begin{array}{l}\text { Large-chain } \\
\& \text { Non-Chain } \\
\text { Grocery } \\
\text { Stores }\end{array}$ & $\begin{array}{l}\text { Large } \\
\text { Chain } \\
\text { Grocery }\end{array}$ & $\begin{array}{c}\text { Non-Chain } \\
\text { Grocery }\end{array}$ & $\begin{array}{l}\text { Non- } \\
\text { Grocery }\end{array}$ & \\
\hline Black & $\begin{array}{c}0.55 \\
(0.05)\end{array}$ & $\begin{array}{c}1.14^{\mathrm{a}} \\
(0.11)\end{array}$ & $\begin{array}{c}0.91^{\mathrm{a}} \\
(0.12)\end{array}$ & $\begin{array}{c}0.25^{\mathrm{a}} \\
(0.03)\end{array}$ & $\begin{array}{l}89.4 \\
(3.9)\end{array}$ & $\begin{array}{l}51.0 \\
(7.2)\end{array}$ & $\begin{array}{l}74.6^{\mathrm{a}} \\
(6.1)\end{array}$ & $\begin{array}{l}97.7 \\
(1.8)\end{array}$ & 668 \\
\hline Households with Children & $\begin{array}{c}0.61 \\
(0.08)\end{array}$ & $\begin{array}{c}0.92 \\
(0.11)\end{array}$ & $\begin{array}{c}1.28 \\
(0.16)\end{array}$ & $\begin{array}{c}0.35 \\
(0.05)\end{array}$ & $\begin{array}{l}85.1 \\
(5.7)\end{array}$ & $\begin{array}{c}63.4 \\
(8.1))\end{array}$ & $\begin{array}{l}49.8 \\
(6.5)\end{array}$ & $\begin{array}{l}96.1 \\
(2.3)\end{array}$ & 488 \\
\hline Households without Children & $\begin{array}{c}0.66 \\
(0.08)\end{array}$ & $\begin{array}{c}1.03 \\
(0.11)\end{array}$ & $\begin{array}{c}1.30 \\
(0.16)\end{array}$ & $\begin{array}{c}0.36 \\
(0.04)\end{array}$ & $\begin{array}{l}83.0 \\
(5.1)\end{array}$ & $\begin{array}{l}58.1 \\
(7.8)\end{array}$ & $\begin{array}{l}55.2 \\
(8.1)\end{array}$ & $\begin{array}{l}94.4 \\
(3.7)\end{array}$ & 472 \\
\hline Income at or below $100 \%$ of FPL & $\begin{array}{c}0.54^{\mathrm{a}} \\
(0.05)\end{array}$ & $\begin{array}{c}1.04 \\
(0.11)\end{array}$ & $\begin{array}{l}1.01^{\mathrm{a}} \\
(0.11)\end{array}$ & $\begin{array}{r}0.28^{\mathrm{a}} \\
(0.03)\end{array}$ & $\begin{array}{l}88.1 \\
(4.5)\end{array}$ & $\begin{array}{l}54.9 \\
(7.5)\end{array}$ & $\begin{array}{l}67.2^{\mathrm{a}} \\
(5.7)\end{array}$ & $\begin{array}{l}98.5 \\
(1.4)\end{array}$ & 459 \\
\hline Detroit Resident & $\begin{array}{c}0.50^{\mathrm{a}} \\
(0.07)\end{array}$ & $\begin{array}{l}1.28^{\mathrm{a}} \\
(0.12)\end{array}$ & $\begin{array}{l}0.58^{\mathrm{a}} \\
(0.07)\end{array}$ & $\begin{array}{l}0.19^{\mathrm{a}} \\
(0.02)\end{array}$ & $\begin{array}{l}92.4 \\
(4.4)\end{array}$ & $\begin{array}{l}42.4^{\mathrm{a}} \\
(8.4)\end{array}$ & $\begin{array}{l}89.8^{\mathrm{a}} \\
(4.6)\end{array}$ & $\begin{array}{c}100.0^{\mathrm{a}} \\
(0.0)\end{array}$ & 520 \\
\hline Suburban Resident & $\begin{array}{c}0.71^{\mathrm{a}} \\
(0.09)\end{array}$ & $\begin{array}{c}0.83^{\mathrm{a}} \\
(0.14)\end{array}$ & $\begin{array}{c}1.65^{\mathrm{a}} \\
(0.21)\end{array}$ & $\begin{array}{c}0.44^{\mathrm{a}} \\
(0.06)\end{array}$ & $\begin{array}{l}79.7 \\
(6.7)\end{array}$ & $\begin{array}{l}69.3^{\mathrm{a}} \\
(9.2)\end{array}$ & $\begin{array}{c}34.6^{\mathrm{a}} \\
(10.4)\end{array}$ & $\begin{array}{l}92.7^{\mathrm{a}} \\
(3.8)\end{array}$ & 439 \\
\hline Work-limiting Health Condition & $\begin{array}{c}0.61 \\
(0.07)\end{array}$ & $\begin{array}{c}1.07 \\
(0.12)\end{array}$ & $\begin{array}{l}1.11^{\mathrm{a}} \\
(0.12)\end{array}$ & $\begin{array}{c}0.30^{\mathrm{a}} \\
(0.03)\end{array}$ & $\begin{array}{l}87.3 \\
(5.4)\end{array}$ & $\begin{array}{l}57.5 \\
(9.2)\end{array}$ & $\begin{array}{l}64.6^{\mathrm{a}} \\
(6.4)\end{array}$ & $\begin{array}{l}97.3 \\
(1.8)\end{array}$ & 277 \\
\hline No Work-limiting Health Condition & $\begin{array}{c}0.65 \\
(0.07)\end{array}$ & $\begin{array}{c}.95 \\
(0.09)\end{array}$ & $\begin{array}{c}1.36^{\mathrm{a}} \\
(0.14)\end{array}$ & $\begin{array}{c}0.37^{\mathrm{a}} \\
(0.04)\end{array}$ & $\begin{array}{l}82.7 \\
(4.9)\end{array}$ & $\begin{array}{l}61.4 \\
(7.3)\end{array}$ & $\begin{array}{l}48.7^{\mathrm{a}} \\
(6.9)\end{array}$ & $\begin{array}{l}94.4 \\
(2.8)\end{array}$ & 683 \\
\hline Food Insecure & $\begin{array}{l}0.61 \\
(.07)\end{array}$ & $\begin{array}{l}1.02 \\
(.10)\end{array}$ & $\begin{array}{l}1.16 \\
(.10)\end{array}$ & $\begin{array}{l}.31^{\mathrm{a}} \\
(.03)\end{array}$ & $\begin{array}{l}84.5 \\
(5.3)\end{array}$ & $\begin{array}{l}56.5 \\
(7.8)\end{array}$ & $\begin{array}{l}57.0^{\mathrm{a}} \\
(4.8)\end{array}$ & $\begin{array}{l}98.5^{\mathrm{a}} \\
(1.1)\end{array}$ & 417 \\
\hline Food Secure & $\begin{array}{l}0.66 \\
(.07)\end{array}$ & $\begin{array}{c}.95 \\
(.10)\end{array}$ & $\begin{array}{l}1.37 \\
(.17)\end{array}$ & $\begin{array}{l}.38^{\mathrm{a}} \\
(.05)\end{array}$ & $\begin{array}{l}83.6 \\
(4.9)\end{array}$ & $\begin{array}{l}62.7 \\
(7.4)\end{array}$ & $\begin{array}{l}50.3^{\mathrm{a}} \\
(8.3)\end{array}$ & $\begin{array}{l}93.1^{\mathrm{a}} \\
(3.6)\end{array}$ & 543 \\
\hline Household Has No Car & $\begin{array}{c}0.60 \\
(0.07)\end{array}$ & $\begin{array}{c}1.12^{\mathrm{a}} \\
(0.10)\end{array}$ & $\begin{array}{l}1.11^{\mathrm{a}} \\
(0.16)\end{array}$ & $\begin{array}{c}0.30^{\mathrm{a}} \\
(0.04)\end{array}$ & $\begin{array}{l}83.5 \\
(5.2)\end{array}$ & $\begin{array}{l}50.0 \\
(7.3)\end{array}$ & $\begin{array}{l}65.8^{\mathrm{a}} \\
(7.4)\end{array}$ & $\begin{array}{l}97.6 \\
(1.8)\end{array}$ & 379 \\
\hline
\end{tabular}




\begin{tabular}{|c|c|c|c|c|c|c|c|c|c|c|}
\hline \multicolumn{11}{|c|}{$\begin{array}{l}\text { TABLE } 3 \\
\text { Number of SNAP Retailers Nearby Households with Income at or Below } 300 \% \text { of Poverty }\end{array}$} \\
\hline \multirow[b]{2}{*}{ Respondent Characteristics } & \multicolumn{3}{|c|}{$\begin{array}{c}\text { Number of SNAP Retailers } \\
\text { within } 1 \text { mile } \\
\end{array}$} & \multicolumn{3}{|c|}{$\begin{array}{c}\text { Number of SNAP Retailers } \\
\text { within } 2 \text { miles }\end{array}$} & \multicolumn{3}{|c|}{$\begin{array}{c}\begin{array}{c}\text { Number of SNAP Retailers } \\
\text { within } 3 \text { miles }\end{array} \\
\end{array}$} & \multirow[b]{2}{*}{$n$} \\
\hline & $\begin{array}{l}\text { Large- } \\
\text { chain } \\
\text { Grocery }\end{array}$ & $\begin{array}{c}\text { Non- } \\
\text { Chain } \\
\text { Grocery }\end{array}$ & $\begin{array}{c}\text { Non- } \\
\text { Grocery }\end{array}$ & $\begin{array}{l}\text { Large- } \\
\text { chain } \\
\text { Grocery }\end{array}$ & $\begin{array}{c}\text { Non- } \\
\text { Chain } \\
\text { Grocery }\end{array}$ & $\begin{array}{c}\text { Non- } \\
\text { Grocery }\end{array}$ & $\begin{array}{c}\text { Large- } \\
\text { chain } \\
\text { Grocery }\end{array}$ & $\begin{array}{c}\text { Non- } \\
\text { Chain } \\
\text { Grocery }\end{array}$ & $\begin{array}{c}\text { Non- } \\
\text { Grocery }\end{array}$ & \\
\hline Black & $\begin{array}{l}0.7^{\mathrm{a}} \\
(0.1)\end{array}$ & $\begin{array}{l}1.9^{\mathrm{a}} \\
(0.3)\end{array}$ & $\begin{array}{l}25.1^{\mathrm{a}} \\
(2.1)\end{array}$ & $\begin{array}{l}2.4^{\mathrm{a}} \\
(0.2)\end{array}$ & $\begin{array}{l}5.2^{\mathrm{a}} \\
(0.5)\end{array}$ & $\begin{array}{l}84.3^{\mathrm{a}} \\
(5.4)\end{array}$ & $\begin{array}{l}5.3^{\mathrm{a}} \\
(0.3)\end{array}$ & $\begin{array}{l}11.2^{\mathrm{a}} \\
(0.9)\end{array}$ & $\begin{array}{l}170.3^{\mathrm{a}} \\
(10.7)\end{array}$ & 668 \\
\hline Non-black & $\begin{array}{c}1.4^{\mathrm{a}} \\
(0.4)\end{array}$ & $\begin{array}{r}0.5^{\mathrm{a}} \\
(0.1)\end{array}$ & $\begin{array}{r}9.3^{\mathrm{a}} \\
(1.2)\end{array}$ & $\begin{array}{l}4.1^{\mathrm{a}} \\
(0.5)\end{array}$ & $\begin{array}{l}1.8^{\mathrm{a}} \\
(0.3)\end{array}$ & $\begin{array}{l}32.2^{\mathrm{a}} \\
(3.3)\end{array}$ & $\begin{array}{l}8.4^{\mathrm{a}} \\
(0.6)\end{array}$ & $\begin{array}{c}3.4^{\mathrm{a}} \\
(0.5)\end{array}$ & $\begin{array}{l}67.3^{\mathrm{a}} \\
(5.3)\end{array}$ & 292 \\
\hline Households with Children & $\begin{array}{l}1.2 \\
(0.4)\end{array}$ & $\begin{array}{l}1.0 \\
(0.2)\end{array}$ & $\begin{array}{l}16.2 \\
(1.4)\end{array}$ & $\begin{array}{c}3.2 \\
(0.4)\end{array}$ & $\begin{array}{l}3.3 \\
(0.4)\end{array}$ & $\begin{array}{l}56.2 \\
(3.6)\end{array}$ & $\begin{array}{c}6.9 \\
(0.4)\end{array}$ & $\begin{array}{c}6.7 \\
(0.6)\end{array}$ & $\begin{array}{c}113.9 \\
(6.6)\end{array}$ & 488 \\
\hline Households without Children & $\begin{array}{l}1.0 \\
(0.3)\end{array}$ & $\begin{array}{c}1.2 \\
(0.2)\end{array}$ & $\begin{array}{l}16.2 \\
(1.8)\end{array}$ & $\begin{array}{c}3.4 \\
(0.4)\end{array}$ & $\begin{array}{c}3.3 \\
(0.4)\end{array}$ & $\begin{array}{l}53.9 \\
(4.9)\end{array}$ & $\begin{array}{l}7.1 \\
(0.5)\end{array}$ & $\begin{array}{c}6.9 \\
(0.9)\end{array}$ & $\begin{array}{l}110.9 \\
(10.4)\end{array}$ & 472 \\
\hline Income at or below $100 \%$ of FPL & $\begin{array}{c}0.9 \\
(0.2)\end{array}$ & $\begin{array}{l}1.6^{\mathrm{a}} \\
(0.3)\end{array}$ & $\begin{array}{l}21.3^{\mathrm{a}} \\
(2.1)\end{array}$ & $\begin{array}{l}2.8^{\mathrm{a}} \\
(0.3)\end{array}$ & $\begin{array}{r}4.3^{\mathrm{a}} \\
(0.5)\end{array}$ & $\begin{array}{l}71.0^{\mathrm{a}} \\
(5.4)\end{array}$ & $\begin{array}{l}5.9^{\mathrm{a}} \\
(0.4)\end{array}$ & $\begin{array}{l}9.3^{\mathrm{a}} \\
(0.9)\end{array}$ & $\begin{array}{l}144.3^{\mathrm{a}} \\
(10.9)\end{array}$ & 459 \\
\hline Income $100-300 \%$ of FPL & $\begin{array}{c}1.2 \\
(0.3)\end{array}$ & $\begin{array}{c}0.9^{\mathrm{a}} \\
(0.1)\end{array}$ & $\begin{array}{l}13.4^{\mathrm{a}} \\
(1.1)\end{array}$ & $\begin{array}{r}3.6^{\mathrm{a}} \\
(0.4)\end{array}$ & $\begin{array}{l}2.7^{\mathrm{a}} \\
(0.3)\end{array}$ & $\begin{array}{l}46.3^{\mathrm{a}} \\
(2.9)\end{array}$ & $\begin{array}{l}7.7^{\mathrm{a}} \\
(0.4)\end{array}$ & $\begin{array}{r}5.5^{\mathrm{a}} \\
(0.5)\end{array}$ & $\begin{array}{l}94.9^{\mathrm{a}} \\
(5.6)\end{array}$ & 501 \\
\hline Detroit Resident & $\begin{array}{l}0.5^{\mathrm{a}} \\
(0.1)\end{array}$ & $\begin{array}{l}2.5^{\mathrm{a}} \\
(0.4)\end{array}$ & $\begin{array}{l}31.4^{\mathrm{a}} \\
(2.1)\end{array}$ & $\begin{array}{l}2.2^{\mathrm{a}} \\
(0.3)\end{array}$ & $\begin{array}{c}6.8^{\mathrm{a}} \\
(0.5)\end{array}$ & $\begin{array}{l}104.7^{\mathrm{a}} \\
(3.6)\end{array}$ & $\begin{array}{l}4.5^{\mathrm{a}} \\
(0.5)\end{array}$ & $\begin{array}{l}14.2^{\mathrm{a}} \\
(0.7)\end{array}$ & $\begin{array}{c}210.5^{\mathrm{a}} \\
(8.0)\end{array}$ & 52 \\
\hline Suburban Resident & $\begin{array}{c}1.4^{\mathrm{a}} \\
(0.4)\end{array}$ & $\begin{array}{c}0.4^{\mathrm{a}} \\
(0.1)\end{array}$ & $\begin{array}{c}8.6^{\mathrm{a}} \\
(1.0)\end{array}$ & $\begin{array}{c}3.9^{\mathrm{a}} \\
(0.5)\end{array}$ & $\begin{array}{c}1.5^{\mathrm{a}} \\
(0.3)\end{array}$ & $\begin{array}{l}30.4^{\mathrm{a}} \\
(2.9)\end{array}$ & $\begin{array}{l}8.3^{\mathrm{a}} \\
(0.5)\end{array}$ & $\begin{array}{c}3.2^{\mathrm{a}} \\
(0.5)\end{array}$ & $\begin{array}{l}63.6^{\mathrm{a}} \\
(4.5)\end{array}$ & 430 \\
\hline Work-limiting Health Condition & $\begin{array}{l}1.0 \\
(0.3)\end{array}$ & $\begin{array}{l}1.6^{\mathrm{a}} \\
(0.4)\end{array}$ & $\begin{array}{l}19.9^{\mathrm{a}} \\
(2.7)\end{array}$ & $\begin{array}{l}3.3 \\
(0.5)\end{array}$ & $\begin{array}{l}4.0^{\mathrm{a}} \\
(0.5)\end{array}$ & $\begin{array}{l}63.8^{\mathrm{a}} \\
(5.9)\end{array}$ & $\begin{array}{c}6.5 \\
(0.6)\end{array}$ & $\begin{array}{c}8.1^{\mathrm{a}} \\
(1.1)\end{array}$ & $\begin{array}{l}127.5^{\mathrm{a}} \\
(11.9)\end{array}$ & 277 \\
\hline No Work-limiting Health Condition & $\begin{array}{c}1.1 \\
(0.3)\end{array}$ & $\begin{array}{c}0.9^{\mathrm{a}} \\
(0.1)\end{array}$ & $\begin{array}{l}14.9^{\mathrm{a}} \\
(1.1)\end{array}$ & $\begin{array}{c}3.4 \\
(0.3)\end{array}$ & $\begin{array}{c}3.0^{\mathrm{a}} \\
(0.3)\end{array}$ & $\begin{array}{l}51.8^{\mathrm{a}} \\
(3.0)\end{array}$ & $\begin{array}{c}7.2 \\
(0.4)\end{array}$ & $\begin{array}{c}6.4^{\mathrm{a}} \\
(0.5)\end{array}$ & $\begin{array}{c}106.8^{\mathrm{a}} \\
(6.1)\end{array}$ & 683 \\
\hline Food Insecure & $\begin{array}{c}1.0 \\
(0.2)\end{array}$ & $\begin{array}{l}1.3^{\mathrm{a}} \\
(0.2)\end{array}$ & $\begin{array}{l}18.2^{\mathrm{a}} \\
(1.8)\end{array}$ & $\begin{array}{c}3.2 \\
(0.3)\end{array}$ & $\begin{array}{l}3.9^{\mathrm{a}} \\
(0.4)\end{array}$ & $\begin{array}{l}62.4^{\mathrm{a}} \\
(4.8)\end{array}$ & $\begin{array}{c}6.8 \\
(0.3)\end{array}$ & $\begin{array}{l}7.9^{\mathrm{a}} \\
(.09)\end{array}$ & $\begin{array}{c}128.0^{\mathrm{a}} \\
(9.8)\end{array}$ & $41^{\top}$ \\
\hline Food Secure & $\begin{array}{c}1.2 \\
(0.3)\end{array}$ & $\begin{array}{c}1.0^{\mathrm{a}} \\
(0.2)\end{array}$ & $\begin{array}{l}14.9^{\mathrm{a}} \\
(1.2)\end{array}$ & $\begin{array}{c}3.4 \\
(0.4)\end{array}$ & $\begin{array}{c}2.9^{\mathrm{a}} \\
(0.3)\end{array}$ & $\begin{array}{l}50.4^{\mathrm{a}} \\
(3.2)\end{array}$ & $\begin{array}{c}7.2 \\
(0.4)\end{array}$ & $\begin{array}{c}6.2^{\mathrm{a}} \\
(0.5)\end{array}$ & $\begin{array}{c}102.6^{\mathrm{a}} \\
(6.5)\end{array}$ & 543 \\
\hline Household Has No Car & $\begin{array}{c}0.8^{\mathrm{a}} \\
(0.1)\end{array}$ & $\begin{array}{l}1.7^{\mathrm{a}} \\
(0.3)\end{array}$ & $\begin{array}{l}21.3^{\mathrm{a}} \\
(2.5)\end{array}$ & $\begin{array}{l}2.5^{\mathrm{a}} \\
(0.3)\end{array}$ & $\begin{array}{l}4.4^{\mathrm{a}} \\
(0.4)\end{array}$ & $\begin{array}{l}70.0^{\mathrm{a}} \\
(5.3)\end{array}$ & $\begin{array}{l}5.6^{\mathrm{a}} \\
(0.4)\end{array}$ & $\begin{array}{l}9.5^{\mathrm{a}} \\
(0.9)\end{array}$ & $\begin{array}{c}142.3^{\mathrm{a}} \\
(9.9)\end{array}$ & 379 \\
\hline Household Has Car & $\begin{array}{r}1.3^{\mathrm{a}} \\
(0.3) \\
\end{array}$ & $\begin{array}{r}0.9^{\mathrm{a}} \\
(0.1) \\
\end{array}$ & $\begin{array}{l}13.9^{\mathrm{a}} \\
(1.0)\end{array}$ & $\begin{array}{r}3.7^{\mathrm{a}} \\
(0.4) \\
\end{array}$ & $\begin{array}{r}2.8^{\mathrm{a}} \\
(0.3) \\
\end{array}$ & $\begin{array}{l}48.3^{\mathrm{a}} \\
(3.1) \\
\end{array}$ & $\begin{array}{r}7.7^{\mathrm{a}} \\
(0.4) \\
\end{array}$ & $\begin{array}{r}5.7^{\mathrm{a}} \\
(0.6) \\
\end{array}$ & $\begin{array}{l}98.8^{\mathrm{a}} \\
(6.7) \\
\end{array}$ & 581 \\
\hline
\end{tabular}




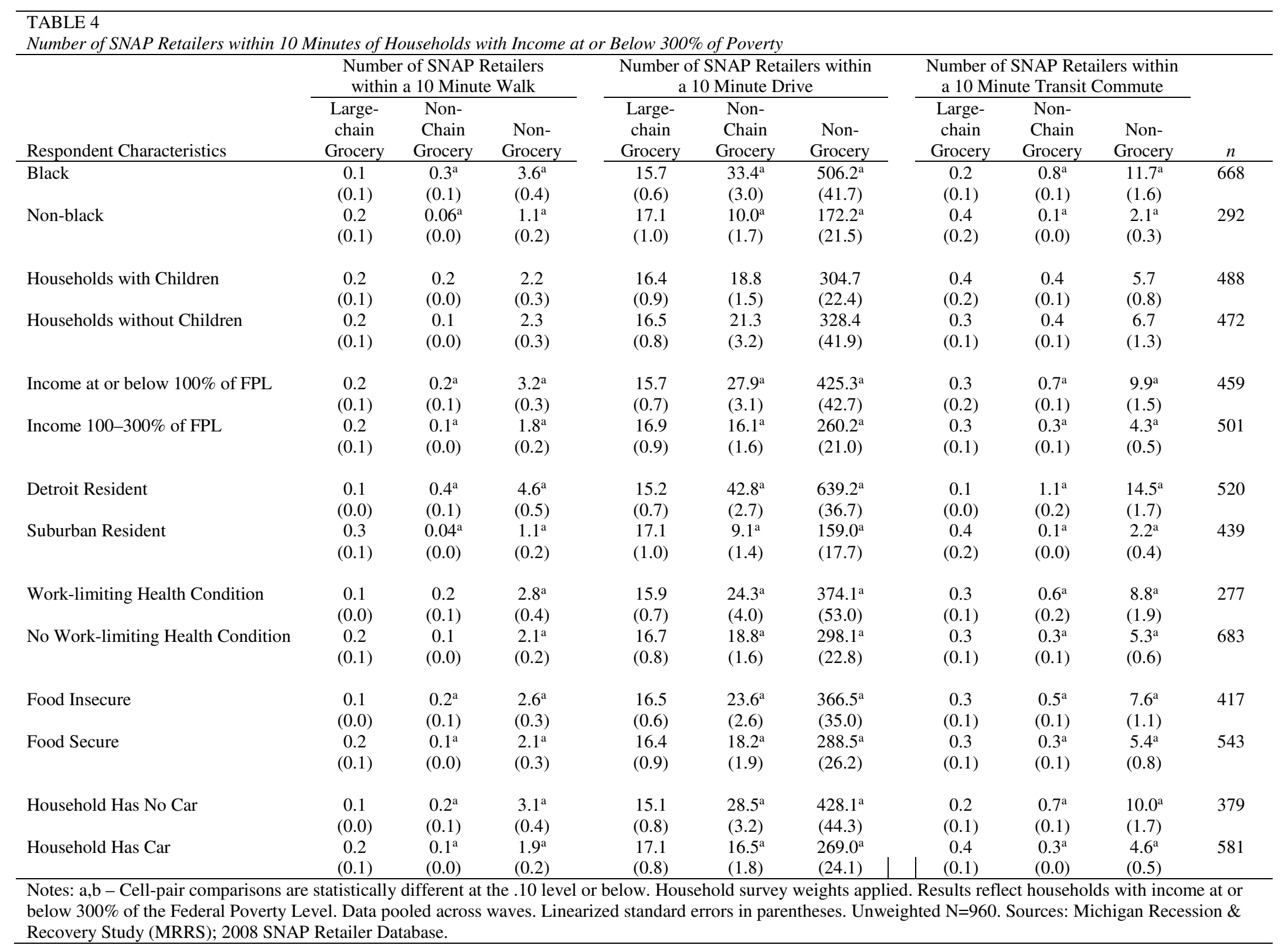




\begin{tabular}{|c|c|c|c|c|}
\hline \multicolumn{5}{|l|}{$\begin{array}{l}\text { TABLE } 5 \\
\text { Factors Associated with Household Fooc }\end{array}$} \\
\hline $\begin{array}{l}\text { Average Distance in Miles to Nearest } \\
\text { SNAP Retailer }\end{array}$ & $(1)$ & $(2)$ & $(3)$ & $(4)$ \\
\hline All Chain \& Non Chain Grocery Stores & $\begin{array}{c}0.931 \\
(0.159)\end{array}$ & & & \\
\hline Large-chain Grocery Stores & & $\begin{array}{r}1.050 \\
(0.136)\end{array}$ & & \\
\hline Non-Chain Grocery Stores & & & $\begin{array}{c}0.903 \\
(0.0929)\end{array}$ & \\
\hline Non Grocery Stores & & & & $\begin{array}{r}0.669 \\
(0.252) \\
\end{array}$ \\
\hline \multicolumn{5}{|l|}{$\begin{array}{l}\text { Respondent or Household } \\
\text { Characteristics }\end{array}$} \\
\hline Respondent Race - Black & $\begin{array}{c}1.072 \\
(0.226)\end{array}$ & $\begin{array}{c}1.066 \\
(0.222)\end{array}$ & $\begin{array}{r}1.020 \\
(0.217)\end{array}$ & $\begin{array}{r}1.027 \\
(0.225)\end{array}$ \\
\hline Households with Children & $\begin{array}{r}0.804 \\
(0.160)\end{array}$ & $\begin{array}{r}0.809 \\
(0.166)\end{array}$ & $\begin{array}{r}0.797 \\
(0.159)\end{array}$ & $\begin{array}{r}0.799 \\
(0.157)\end{array}$ \\
\hline \multicolumn{5}{|l|}{ Respondent Age } \\
\hline 19-24 Years Old & $\begin{array}{r}0.720 \\
(0.215)\end{array}$ & $\begin{array}{r}0.726 \\
(0.221)\end{array}$ & $\begin{array}{c}0.753 \\
(0.239)\end{array}$ & $\begin{array}{r}0.760 \\
(0.230)\end{array}$ \\
\hline 25-34 Years Old & $\begin{array}{r}1.699 * \\
(0.493)\end{array}$ & $\begin{array}{r}1.698^{*} \\
(0.495)\end{array}$ & $\begin{array}{r}1.736^{*} \\
(0.507)\end{array}$ & $\begin{array}{r}1.742 * \\
(0.504)\end{array}$ \\
\hline 35-44 Years Old & $\begin{array}{r}1.349 \\
(0.316)\end{array}$ & $\begin{array}{r}1.354 \\
(0.320)\end{array}$ & $\begin{array}{c}1.374 \\
(0.334)\end{array}$ & $\begin{array}{r}1.385 \\
(0.330)\end{array}$ \\
\hline Respondent Married & $\begin{array}{c}0.844 \\
(0.245)\end{array}$ & $\begin{array}{c}0.857 \\
(0.252)\end{array}$ & $\begin{array}{c}0.849 \\
(0.242)\end{array}$ & $\begin{array}{c}0.865 \\
(0.246)\end{array}$ \\
\hline \multicolumn{5}{|l|}{ Respondent Completed Education } \\
\hline Less than High School & $\begin{array}{l}5.905^{* * *} \\
(2.480)\end{array}$ & $\begin{array}{l}5.841 * * * \\
(2.429)\end{array}$ & $\begin{array}{l}5.822 * * * \\
(2.412)\end{array}$ & $\begin{array}{l}5.648 * * * \\
(2.455)\end{array}$ \\
\hline High School but no BA & $\begin{array}{c}3.732 * * * \\
(1.343)\end{array}$ & $\begin{array}{c}3.725 * * * \\
(1.331)\end{array}$ & $\begin{array}{c}3.729 * * * \\
(1.308)\end{array}$ & $\begin{array}{l}3.625 * * * \\
(1.342)\end{array}$ \\
\hline Household Income $0-100 \%$ Poverty & $\begin{array}{r}1.500^{*} \\
(0.350)\end{array}$ & $\begin{array}{r}1.516^{*} \\
(0.356)\end{array}$ & $\begin{array}{r}1.489^{*} \\
(0.345)\end{array}$ & $\begin{array}{r}1.485 \\
(0.353)\end{array}$ \\
\hline Owns or Leases a Car & $\begin{array}{r}1.337 \\
(0.431)\end{array}$ & $\begin{array}{c}1.343 \\
(0.428)\end{array}$ & $\begin{array}{c}1.344 \\
(0.430)\end{array}$ & $\begin{array}{c}1.343 \\
(0.435)\end{array}$ \\
\hline \multicolumn{5}{|l|}{$\begin{array}{l}\text { Respondent Employment Status in } \\
\text { Previous } 12 \text { Months }\end{array}$} \\
\hline 1-6 mos. unemployed or NILF & $\begin{array}{l}2.077 * * \\
(0.629)\end{array}$ & $\begin{array}{l}2.112 * * \\
(0.641)\end{array}$ & $\begin{array}{l}2.088 * * \\
(0.650)\end{array}$ & $\begin{array}{l}2.069 * * \\
(0.626)\end{array}$ \\
\hline 7-9 mos. unemployed or NILF & $\begin{array}{l}2.083^{*} \\
(0.776)\end{array}$ & $\begin{array}{r}2.093 * \\
(0.778)\end{array}$ & $\begin{array}{l}2.133^{*} \\
(0.801)\end{array}$ & $\begin{array}{l}2.114^{*} \\
(0.794)\end{array}$ \\
\hline 10-12 mos. unemployed or NILF & $\begin{array}{r}1.555 \\
(0.632)\end{array}$ & $\begin{array}{c}1.581 \\
(0.646)\end{array}$ & $\begin{array}{c}1.561 \\
(0.638)\end{array}$ & $\begin{array}{r}1.556 \\
(0.633)\end{array}$ \\
\hline Work-limiting health condition & $\begin{array}{l}2.267 * * \\
(0.684)\end{array}$ & $\begin{array}{l}2.256 * * \\
(0.676)\end{array}$ & $\begin{array}{l}2.269 * * \\
(0.689)\end{array}$ & $\begin{array}{l}2.281 * * \\
(0.689)\end{array}$ \\
\hline \multicolumn{5}{|l|}{ Household Financial Hardship in } \\
\hline Previous 12 Months & $\begin{array}{l}3.503 * * * \\
(0.756)\end{array}$ & $\begin{array}{l}3.499 * * * \\
(0.757)\end{array}$ & $\begin{array}{l}3.517 * * * \\
(0.768)\end{array}$ & $\begin{array}{l}3.505^{* * *} \\
(0.767)\end{array}$ \\
\hline Wave 1 & $\begin{array}{l}1.418 * * \\
(0.227)\end{array}$ & $\begin{array}{l}1.421 * * \\
(0.230)\end{array}$ & $\begin{array}{l}1.415^{* *} \\
(0.231)\end{array}$ & $\begin{array}{l}1.444 * * \\
(0.236)\end{array}$ \\
\hline Constant & $\begin{array}{l}0.0326 * * * \\
(0.0170)\end{array}$ & $\begin{array}{l}0.0291 * * * \\
(0.0159)\end{array}$ & $\begin{array}{l}0.0357 * * * \\
(0.0175)\end{array}$ & $\begin{array}{l}0.0362 * * * \\
(0.0205)\end{array}$ \\
\hline \multicolumn{5}{|c|}{$(0.010)$} \\
\hline $\begin{array}{l}\text { Note: Unweighted } \mathrm{N}=960 \text {. Odds ratios } \\
\text { were estimated using pooled data, house } \\
\text { categorical predictors are: Age ( } 45 \text { and } \\
\text { Income (Between } 100-300 \% \text { of poverty } \\
\text { Retailer Database. } * p<0.1 ; * * p<0.05 ;\end{array}$ & $\begin{array}{l}\text { orted on the } \\
\text { rvey weight } \\
\text { ducation (B. } \\
\text { s: Michigan } \\
01\end{array}$ & $\begin{array}{l}\text { and standarc } \\
\text { istered stand } \\
\text { re), Unempl } \\
\text { on \& Recove }\end{array}$ & $\begin{array}{l}\text { ported in par } \\
\text { Reference c } \\
\text { lo unemployr } \\
\text { MRRS); } 200\end{array}$ & $\begin{array}{l}\text { Models } \\
\text { for } \\
\text { pusehold } \\
10 \text { SNAP }\end{array}$ \\
\hline
\end{tabular}




\begin{tabular}{|c|c|}
\hline \multicolumn{2}{|c|}{$\begin{array}{l}\text { TABLE } 6 \\
\text { Relationship between Food Resource Access and Food Insecurity among Households at or } \\
\text { below 300\% of Poverty - Dichotomous Food Security Measure }\end{array}$} \\
\hline Measure of Food Resource Access & $\begin{array}{c}\text { Odds Ratio } \\
\text { (Standard Error) }\end{array}$ \\
\hline \# of SNAP Large-chain Groceries within 1 mile & $\begin{array}{c}0.738 \\
(0.941)\end{array}$ \\
\hline \# of SNAP Non-chain Groceries within 1 mile & $\begin{array}{c}1.003 \\
(0.059)\end{array}$ \\
\hline \# of SNAP Non-grocery Retailers within 1 mile & $\begin{array}{c}0.998 \\
(0.008)\end{array}$ \\
\hline \# of SNAP Large-chain Groceries within 3 miles & $\begin{array}{c}1.009 \\
(0.033)\end{array}$ \\
\hline \# of SNAP Non-chain Groceries within 3 miles & $\begin{array}{c}1.002 \\
(0.019)\end{array}$ \\
\hline \# of SNAP Non-grocery Retailers within 3 miles & $\begin{array}{c}1.001 \\
(0.002)\end{array}$ \\
\hline$\%$ of households w/in 1 mile of any SNAP Grocery & $\begin{array}{c}1.132 \\
(0.310)\end{array}$ \\
\hline$\%$ of households w/in 1 mile of a SNAP Large-chain Grocery & $\begin{array}{c}0.938 \\
(0.185)\end{array}$ \\
\hline$\%$ of households w/in 1 mile of a SNAP Non-chain Grocery & $\begin{array}{c}1.007 \\
(0.173)\end{array}$ \\
\hline$\%$ of households w/in 1 mile of a SNAP Non-Grocery & $\begin{array}{l}3.913 * \\
(1.940)\end{array}$ \\
\hline \# SNAP retailers within 10 Min Drive - Large-chain Grocery & $\begin{array}{c}1.011 \\
(0.017)\end{array}$ \\
\hline \# SNAP retailers within 10 Min Drive - Non Chain Grocery & $\begin{array}{c}1.004 \\
(0.007)\end{array}$ \\
\hline \# SNAP retailers within 10 Min Drive - Non-Grocery & $\begin{array}{c}1.000 \\
(0.000)\end{array}$ \\
\hline \# SNAP retailers within 10 Min Public Transit - Large-chain Grocery & $\begin{array}{c}0.915 \\
(0.093)\end{array}$ \\
\hline \# SNAP retailers within 10 Min Public Transit - Non Chain Grocery & $\begin{array}{c}1.079 \\
(0.108)\end{array}$ \\
\hline \# SNAP retailers within 10 Min Public Transit - Non-Grocery & $\begin{array}{c}1.003 \\
(0.009)\end{array}$ \\
\hline \# SNAP retailers within 10 Min Walk - Large-chain Grocery & $\begin{array}{l}0.566 * * \\
(0.120)\end{array}$ \\
\hline \# SNAP retailers within 10 Min Walk - Non Chain Grocery & $\begin{array}{c}1.105 \\
(0.216)\end{array}$ \\
\hline \# SNAP retailers within 10 Min Walk - Non-Grocery & $\begin{array}{c}0.995 \\
(0.037) \\
\end{array}$ \\
\hline
\end{tabular}

Note: Unweighted $\mathrm{N}=960$. Logit models were estimated using pooled data, household survey weights, and clustered standard errors. Odds ratios are reported on the first line and standard errors reported in parentheses. Reported odds ratios and standard errors are drawn from separate logit regression models using the same set of control variables as shown in Table 5, but only the listed access measure. Results for these other control variables are nearly identical to those reported in Table 5, so we report only the odds ratios and standard errors for the individual access measures entered separately into these models. Source: Michigan Recession \& Recovery Study (MRRS). * $p<0.1 ; * * p<0.05 ; * * * p<0.01$ 


\section{References}

Adams, Terry K., Jim Lepkowski, Mahmoud Elkasabi, and Danielle Battle. 2011. Michigan Recession and Recovery Study (MRRS): Sampling and weights documentation. University of Michigan, Institute for Social Research.

Andrews, Margaret and David Smallwood. 2012. "What's Behind the Rise in SNAP Participation?" U.S. Department of Agriculture, Economic Research Service.

Bartfeld, Judith S., Jeong-Hee Ryu, and Lingling Wang. 2010. "Local Characteristics Are Linked to Food Insecurity among Households with Elementary School Children." Journal of Hunger \& Environmental Nutrition, 5 (4): 471-83.

Berube, Alan and Elizabeth Kneebone. 2013. Confronting Suburban Poverty in America. Washington, D.C.: Brookings Institution Press.

Bitler, Marianne and Steven J. Haider. 2011. "An Economic View of Food Deserts in the United States.” Journal of Policy Analysis and Management, 30 (1): 153-76.

Campbell, Cathy, and Ellen Desjardins 1989. "A model and research approach for studying the management of limited food resources by low income families." Journal of Nutrition Education, 21 (4): 162-70.

Chung, Chanjin, and Samuel L. Myers. 1999. "Do the poor pay more for food? An analysis of grocery store availability and food price disparities." The Journal of Consumer Affairs, 33 (2): 276-296.

Clay, Marie, Michele Ver Ploeg, Alisha Coleman-Jensen, Howard Elitzak, Christian Gregory, David Levin, Constance Newman, and Matthew P. Rabbitt. July 2016. Comparing National Household Food Acquisition and Purchase Survey (FoodAPS) Data with Other National Food Surveys' Data, EIB-157, U.S. Department of Agriculture, Economic ResearchService. https://www.ers.usda.gov/publications/pubdetails/?pubid=79892Coleman-Jensen, Alisha, William McFall, and Mark Nord. 2013. "Food Insecurity in Households with Children: Prevalence, Severity, and Household Characteristics, 2010-11.” U.S. Department of Agriculture, Economic Research Service, Economic Information Bulletin, Number 113.

Coleman-Jensen, Alisha, Mark Nord, Margaret Andrews, Steven Carlson. 2012. "Household Food Security in the United States in 2011." United States Department of Agriculture, Economic Research Service, Economic Research Report, Number 141.

Coleman-Jensen, Alisha, Matthew P. Rabbit, Christian A. Gregory, and Anita Singh. 2016. "Household Food Security in the United States in 2015." U.S. Department of Agriculture, Economic Research Service, ERR-155. http://www.ers.usda.gov/media/2137663/err215.pdf. 
Farley, Reynolds, Sheldon Danziger, and Harry J. Holzer. 2002. Detroit Divided. New York: Russell Sage Foundation.

Gallagher, Mari. 2006. "Examining the Impact of Food Deserts on Public Health in Chicago." Chicago: Mari Gallagher Research \& Consulting Group. http://www.marigallagher.com/site_media/dynamic/project_files/1_ChicagoFoodDesertR eport-Full_.pdf.

Ganong, Peter and Jeffrey B. Liebman. 2013. "The Decline, Rebound, and Further Rise in SNAP Enrollment: Disentangling Business Cycle Fluctuations and Policy Changes." NBER Working Paper, No. 19363.

Gregory, Christian A. and Alisha Coleman-Jensen. 2013. "Do High Food Prices Increase Food Insecurity in the United States." Applied Economic Perspectives and Policy, 35 (4): 679707.

Gruber, Jonathan, and Kosali Simon. 2008. "Crowd-Out Ten Years Later: Have Recent Public Insurance Expansions Crowded Out Private Health Insurance?” Journal of Health Economics, 27 (2008): 201-17.

Gundersen, Craig, Brent Kreider, and John Pepper. 2011. "The Economics of Food Insecurity in the United States." Applied Economic Perspectives and Policy, 33 (3): 281-303.

Hendrickson, Deja, Chery Smith, and Nicole Eikenberry. 2006. "Fruit and vegetable access in four low-income food deserts communities in Minnesota." Agriculture and Human Values, 23: 371-383.

Klerman, Jacob A. and Caroline Danielson. 2011. "The Transformation of the Supplemental Nutrition Assistance Program.” Journal of Policy Analysis and Management, 30 (4), 863-88.

Kreider, Brent, John V. Pepper, Craig Gundersen and Dean Jolliffe. 2012. "Identifying the Effects of SNAP (Food Stamps) on Child Health Outcomes When Participation is Endogenous and Misreported." Journal of the American Statistical Association, 107 (499), 958-975.

Moore, Latetia and Ana V. Diez Roux. 2006. "Associations of Neighborhood Characteristics with the Location and Type of Food Stores." American Journal of Public Health, 96 (2): $1-7$.

Morris, Patricia McGrath, Linda Neuhauser, and Cathy Campbell. 1992. "Food Security in Rural America: A Study of the Availability and Cost of Food." Journal of Nutrition Education, 24 (1): 52S-58S. 
Nord, Mark. 2002. "Rates of Food Insecurity and Hunger Unchanged in Rural Households." Rural America, 16 (4): 42-47.

Nord, Mark, Alisha Coleman-Jensen, Margaret Andrews, and Steven Carlson. 2010. "Household Food Security in the United States, 2009." USDA, Economic Research Service, Economic Research Report No. 108.

Nord, Mark and Anne Marie Golla. 2009. “Does SNAP Decrease Food Insecurity?” U. S. Department of Agriculture, Economic Research Service. Economic Research Report No. 85.

Oliveira, Victor. 2016. “The Food Assistance Landscape: FY 2015 Annual Report.” U.S. Department of Agriculture, Economic Research Service, Economic Information Bulletin, Number 150.

Pan, Suwen and Helen Jensen. 2008. "Does the food stamp program affect food security status and the composition of food expenditures?" Journal of Agricultural and Applied Economics, 40 (1): 21-35.

Powell, Lisa M., Sandy Slater, Donka Mirtcheva, Yanjun Bao, Frank J. Chaloupka. 2007. "Food Store Availability and Neighborhood Characteristics in the United States." Preventive Medicine 44 (2007): 189-95.

Raja, Samina, Changxing Ma, and Pavan Yadav. 2007. "Beyond Food Deserts: Measuring and Mapping Racial Disparities in Neighborhood Food Environments." Journal of Planning Education and Research, 27: 469-82.

Ratcliffe, Caroline, Signe-Mary McKernan, and Kenneth Finegold. 2008. "Effects of Food Stamp and TANF Policies on Food Stamp Program Participation." Social Service Review, 82: 291-334.

Rose, Donald and Rickelle Richards. 2004. "Food Store Access and Household Fruit and Vegetable Use Among Participants in the US Food Stamp Program." Public Health Nutrition, 7 (8): 1081-88.

Shaefer, H. Luke, Grogan, Colleen M., and Pollack, Harold A. (2011). "Transitions from Private to Public Health Coverage Among Children: Estimating Effects on Out-Of-Pocket Medical Costs and Health Insurance Premium Costs." Health Services Research, 46(3): 840-58.

Shaefer, H. Luke. \& Italo Gutierrez. 2013. "The Supplemental Nutrition Assistance Program and material hardships among low-income households with children." Social Service Review, 87 (4): 753-779.

Sullivan, James, Lesley Turner, and Sheldon Danziger. 2008. "The Relationship between Income and Material Hardship." Journal of Policy Analysis and Management, 27: 63-81. 
Taylor, Dorceta E., and Kerry J. Ard. 2015. "Food Availability and the Food Desert Frame in Detroit: An Overview of the City's Food System." Environmental Practice, 17 (2): 10233.

US Department of Agriculture. 2009. "Access to Affordable and Nutritious Food: Measuring and Understanding Food Deserts and Their Consequences." http://www.ers.usda.gov/media/242675/ap036_1_.pdf.

US Department of Agriculture. 2016. "Definition of a Food Desert." http://www.ers.usda.gov/dataFiles/Food_Access_Research_Atlas/Download_the_Data/A rchived_Version/archived_documentation.pdf.

Ver Ploeg, Michele, Vince Breneman, Paula Dutko, Ryan Williams, Samantha Snyder, Chris Dicken, and Phil Kaufman. November 2012. Access to Affordable and Nutritious Food: Updated Estimates of Distance to Supermarkets Using 2010 Data, ERR-143, US Department of Agriculture, Economic Research Service.

Walker, Robert E., Christopher R. Keane, and Jessica G. Burke. 2010. "Disparities and access to healthy food in the United States: A review of food deserts literature."

Yen, Steven T., Margaret Andrews, Zhuo Chen, and David B. Eastwood. 2008. "Food stamp participation and food insecurity: An instrumental variables approach." American Journal of Agricultural Economics, 90 (1): 117-32.

Zenk, Shannon N. Amy J. Schulz, Barbara A. Isreal, Sherman A. James, Shuming Bao and Mark L. Wilson. 2005. "Neighborhood Racial Composition, Neighborhood Poverty, and the Spatial Accessibility of Supermarkets in Metropolitan Detroit." American Journal of Public Health, 95 (4): 660-67. 